\title{
The relation between religion and state in Islam and Christianity in the rise of ISIS
}

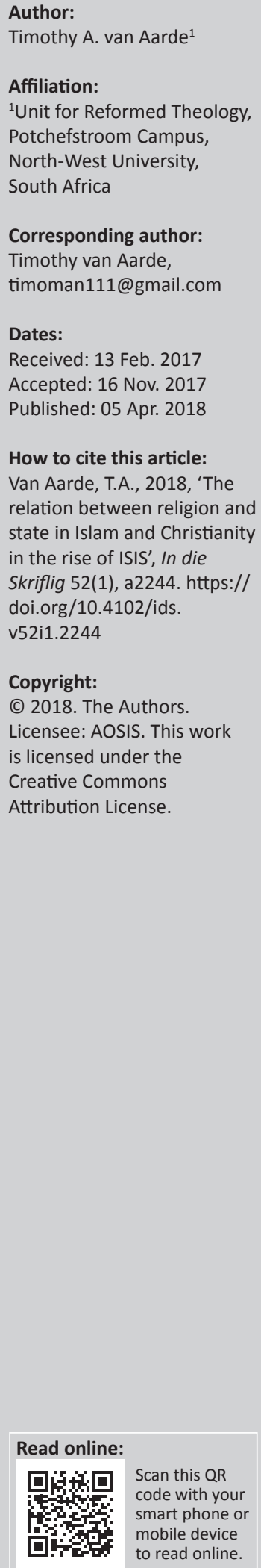

The recent development of the Islamic State (ISIS 2010-2014 and IS 2014) is a radicalisation of the relation between religion and state in Islam. The relation of religion and state to Christianity has been shaped by the philosophy of dualism and Greek thought in the West. The relation of religion and state in Islam, however, has been shaped by a completely different tradition and conflicting view than Western thought and is based on the codified system of Shari'a law in Arabic thought. One of the most debated topics in Islamic studies is the inseparable nature of religion and state in Islam and the role of Shari'a law to the state. In the West the historical debate concerns the indiscriminate blending of church and state and the separation of church and state as indispensable to democracy and the modern question of the relation of Christian morality and public law. Islamic fundamentalism is a political and religious reform movement that indiscriminately blends the political and religious.

\section{Introduction}

There is a debate as to whether there is only a single relation between religion and state or whether multiple possibilities for the relationship between Islam and state exist. It is through the unequivocal application of Shari'a law that Islam and state are inseparably bound together:

It has been generally agreed that after the 9th century there was a closing of the gates of intellectual freedom (or intellectual struggle; ijtihad), with the result that Islamic law - the Shari'a - was perceived as a completely perfect and unchanging body of commands and prohibitions - the 'straight path'. (Huff 1995:512)

The Islamic legal system of Shari'a law developed along a diverse trajectory to Western legal systems which developed sophisticated legal procedures, and adequate penal or commercial codes, human rights and the idea of 'due process' (cf. Huff 1995:512). In the 19th and 20th century the relation between Islam and state in Muslim countries was one of general adoption of some modified version of the Western legal codes. The radical Islamist or neo-fundamental group of which ISIS is one of the most radical manifestations is a movement to purify Islam from Western influences. The unequivocal application of Shari's law leads to a stunning of intellectual horizons ${ }^{1}$ and the illusion of a mystical unity:

Oliver Roy discerns a shift from the early promise of the Islamist program, which held out the possibility of accommodation with modernity, toward a neo-fundamentalist posture, which offers little more than a radical exclusivity based on a literal interpretation of the shari'a, the sacred Islamic law. (Huff 1995:510)

The distinction between the Arabic and Western world is the absolute identification of politics and religion in the Arabic world and the absolute separation of religion and state, as is the case in Western society. The absolute identification of religion and state is fertile ground for a totalitarian state - ISIS is being a prime example - and the complete separation of religion and state is fertile ground for a secular state. The structures of society (societal relations) cannot be separated from the religious direction of a society - the direction influences the structure (cf. Van der Walt 2010:425). The distinction between structure and direction in Christian Philosophy is that structure is connected to creation and direction indicates God's central commandment of love towards him and our fellow creatures. In addressing the relation between religion and state, which in ISIS have been completely fused, the approach of Western political philosophy has been to argue that there should be a complete separation of religion and state. It is the West's absolute separation of religion and state as the basis of democracy that has been perceived as a deliberate undermining of Islam as a system of law. Sharia is not codified which is what makes it difficult for Western nation-states that have a codified law to understand the following:

1.'Scientific activity in the Muslim world remains decidedly unproductive' (Huff 1995:509). 
A major problem of the implementation of Shari'ah law anywhere is that, while it aims to regulate the entire range of human and social activities, from personal to criminal, it has never yet been completely codified according to the cannons of most modern law. (Nagata 1994:68)

In this article the state will be used as a shorthand notation for a set of cohesive institutions, designed to protect orderly relations between individuals and groups and under the direction of a ruler or ruling body within a definable territory. This definition is sufficiently broad to include such forms of political organisation as the Greek polis and the early Islamic Caliphate. It will be suggested that lessons can be learned from the absolute separation of religion and state in the West as one extreme and that lessons can also be learned from Arabic world, and the absolute fusion of religion and state as another extreme. It will be argued that the ideal is neither the separation of religion and state nor the absolute identification of religion and state. The secularist Western culture:

is viewed by various religious groups as profoundly threatening because it enforces secularism on society, overemphasizes individual rights at the expense of social responsibilities and deforms social responsibilities and deforms social institutions and traditions. (Vorster 2007:118) ${ }^{2}$

In this view the role of the state to regulate the moral fabric of society is limited. The radicalised Arabic culture is also viewed as threatening, because it enforces the views of the group on the individual, over-emphasising group rights at the expense of individual responsibility and so results in a state whose role is over-prescriptive in the regulation of the moral fabric of society.

\section{Problem statement}

The increasing unavoidable contact between Western individualistic culture and Arabic communal culture in a globalised world has brought about conflict. The conflict of civilizations has been transposed into a conflict between Christianity and Islam (Christianity representative of the West and Islam representative of the Arabic world). In order to resolve the religious conflict in the public sphere a separation of the public from the private spheres has been introduced in the West. Walls $(1996: 232,234)$ identifies the separation of the public and private spheres as a core element in the expression of Western Christianity. Western Christianity is based on the model of democracy that erroneously conceives of itself as being devoid of religious values. Social policy making and services such as education, health and poverty alleviation are left to the state which claims to be neutral. Lim (2011:66) identifies the roots of the Reformed view of the relation between religion and state as being rooted in participatory democracy. 'The separation of church and state can either be friendly or a hostile separation' (Lilback 2012:84). The hostile or antagonistic separation of church and state is termed secularism. In Western democracy, religious affiliation is subordinate to citizenship, as the state is the final authority - a civil religion. In an Islam state, the state is an institution of religion and legislatively prevents conversions from Islam. Personal civil law and criminal law are under the jurisdiction of Shari'a courts. 'Secularism is itself a religion with its own worldview' (Van der Walt 2007:151). ${ }^{3}$ ISIS is a reaction to Western secularism and democracy, 'regarded as a foreign imposition that was imported by colonialism and as a tool of colonialism to destroy the very foundations of Muslim faith and culture' (Van der Walt 2007:162-163). The role of the state in Islam is to guard against Islamic secularism in contrast to the role of the state in the West whose role it is to guard against radicalisation. The state is conceived as a neutral institution in the West whose task it is to promote equality of all religious traditions. The origins of the historical models for the relation of religion and state in the West and in the Arabic world will be examined and compared, and the factors leading to a fundamentalist and neo-fundamentalist identification of religion and state will be identified.

\section{The formation of ISIS}

It is generally believed that the Islamic State can trace its roots back to the late Abu Musab al-Zarqawi, a Jordanian who set up Tawhid wa al-Jihad (political group) in 2002. A year after the US-led invasion of Iraq, Zarqawi pledged allegiance to Osama Bin Laden and formed al-Qaeda in Iraq (AQI). After Zarqawi's death in 2006, AQI created an umbrella organisation, Islamic State in Iraq (ISIS). Although still nominally tied to al-Qaeda, ISIS was largely an independent group. Relations with AQI unravelled with the onset of the Syrian civil war when Syrian fighters from ISIS, led by Abu Muhammad al-Jawlani, moved back into Iraq and established Jabhat al-Nusrah. ISIS in Iraq was, however, steadily weakened by the US troop surge and the creation of Sahwa [Awakening] councils by Sunni Arab tribesmen who rejected its brutality. Nonetheless, after becoming leader of ISIS in 2010, Abu Bakr al-Baghdadi managed to rebuild their capabilities. After Abu Bakr al-Baghdadi ordered his own men into Syria, he rebranded his group the Islamic State of Iraq and al-Sham (ISIS) in April 2013, and ordered Jabhat al-Nusrah to disband. ISIS became an independent entity from AQI when Al-Qaeda's leader, Ayman al-Zawahiri, disavowed the group in early 2014.

In June 2014, ISIS's leader, Abu Bakr al-Baghdadi, declared the areas of Northern Iraq and Eastern Syria to be a single Islamic state (or 'caliphate') with himself as caliph or supreme political and religious leader. Once declaring the caliphate, ISIS changed its name simply to the Islamic State (IS), claiming that all other Muslim communities should pay homage to IS as the one true Islamic state. A distinction exists between IS and the traditional version of an Islamic state. In order to distinguish between IS and the more traditional version of Islamic state, a distinction is made between IS and Islamic state - the former being the radicalised version.

3.Secularism has replaced the older world religions and the new dominant world wide religion of our times (cf. Van der Walt 2007:151). 


\section{Models for the relation of state and religion}

\section{The relation of politics and religion in the West}

A coalesce of state and religion results either in a religious state or a state religion. Historically Islam has been based on din wa dawla, the unity of state and religion. In the relation between state and religion there are various possibilities, as there is no uniform version of this relation in the Arabic world. The concern of this article is to identify factors that lead to the absolute identification of a religious tradition with the state, resulting in a totalitarian religious state or IS. The political and religious are merged when the distinction between political and moral justice disappears or when there is an avocation for only one form of justice, resulting in a totalitarian religious state governed by an absolute moral or religious justice and a secular state governed by an absolute public justice. In a Western state, public justice is informed by human rights and laws to protect the rights of the individual at the expense of social groupings in society. The essential issue is whether the state is responsible only for public justice and whether or not its role is limited exclusively to the public sphere as well as whether it is private and limited exclusively to the private sphere creating a separation between public and moral justice and so results in the privatisation of religion. It raises the question whether IS is a counter-movement and reaction to the separation of state and religion in the West.

Public and moral justice can both serve a single unity and work towards the same goals and direction or towards opposite goals and direction. Generally, where the two coalesce either religion becomes subservient to politics or politics become subservient to religion. In the merging of politics and religion the tendency is for either the political or religious to be dominant and determines the goals. A conflict of loyalties occurs between the state and religion when the unique task and authority of each is contravened. In Western states the authority of the state is primary in the public sphere, but this is not to be taken to mean that religious laws belong exclusively to the private sphere. A religion is not sovereign only in its own sphere - the private sphere. In order to avoid confusion between the role of the church and state, Lilback (2012:84) uses the term blending of church and state or 'hostile' separation for the confusion of goals in the public sphere and 'the cooperation of church and state' - a 'friendly' separation of church and state with complementary goals in contrast to the conflicting goals of a 'blending of church and state'.

\section{The relation between religion and state in Islam}

The basic principle which governs the relation between religion and state in Islam, is the political sovereignty of Allah overall (cf. Waines 1995:243). The Qur'anic principle (Qur'an 24:55) is that Allah appointed humanity as his vicegerents to rule the earth, and that human government is answerable to Allah (cf. Waines 1995:244):
A major problem of the implementation of Shari'a law anywhere is that, while it aims to regulate the entire range of human and social activities, from personal to criminal, it has never yet been completely codified according to the cannon of modern law. (Nagata 1994:68)

A distinction exists between IS and the traditional Islamic state in the implementation of Shari'a law:

It has been generally agreed that after the 9th century there was a closing of the gates of intellectual freedom (or intellectual struggle; ijtihad), with the result that Islamic law - the Shari'a was perceived as completely perfect and unchanging body of commands and prohibitions - the 'straight path'. (Huff 1995:512)

Mehdi Shokri (2016:3-12) writes that in radical Islam 'Islamic law and a political framework which is the vital instrument for the existence of the current forms of radical Islamic power relation and its aim, i.e. an Islamic state' (p. 5) are blended. The aim of IS to shape an Islamic world order and subdue it to an Islamic power orientated militant group, catalysed by the traditional idea to turn the world into an authoritative Islamic political power, is in essence driven by the same engine as that of a hostile separation of state and religion in the West. IS and a hostile separation of church and state are driven by the same aims and goals of absolute authority.

\section{Jihad}

Jihad is an instrument used by radical Islamists in the establishment of IS.

The relation between religion and state in Islam 'is not a matter of the one using the other' (Boer 2009:131). It is the dual nature of Islam as both political and religious that gives to Islamic radicalism its distinctive character, argues Boer (2009:128). A distinction exists between IS that gives priority to political Islam over religion and the traditional Islamic state that gives priority to the religious. It is thus not the inseparable relation between the political and religious per se that is fertile ground for a radical ideology, but the use of violence and force to bring about Sunni extremism. This is paramount, as the aims and eschatology's of the Sunni's and Shia's differ vastly. Jihad allows the Islamic State to impose political, economic, religious, social and cultural institutions upon a particular group of people (cf. Turaki 2010:64). It is the use of jihad by IS which results in a relation between state and religion is characterised by violence - the sword. The use of the sword to maintain a fundamentalist relation of no separation between religion and state is, in fact, no different from the movement of radical separation and amputation between religion and state in the West. Both are forms of extremism in two diverse directions. 'A successful jihad creates the political power that results in Islam's being made a state religion' (Turaki 2010:65). In terms of the use of violence to bring about a religious state, Jesus warns his disciples that '.. all those who take up the sword shall perish by the sword' (Mt 26:52). Although Shari'a Law has a significant function in the unification of the state, it would be 
a fallacy to conclude that Shari'a Law lends itself to extremism or radicalism just as democracy does not lend itself to perfect liberty.

\section{Jihad and radical ideology}

Two innovations in particular can be credited to the Brotherhood. The first was a truly distinctive ideology of jihad and martyrdom. An even more significant departure from the classical tradition was the assertion that jihad, in the modern context, had become an individual rather than a collective duty. (Brown 2004:216)

The distinction between the IS version of Islamic state and the more moderate version thereof is that the IS ideology advocates for an Islamic state derived in its entirety from the Quran and the Sunna of the Prophet Muhammed (cf. Brown 2004:215). The Muslim Brotherhood is a violent reaction against modernity (cf. Brown 2004:207) so that the argument can be made that IS is a reactionary movement towards the influences of modernism and postmodernism. In IS the meaning and practice of jihad is part of the establishment of an Islamic state. The primary reasons for jihad in IS are a reaction to political and economic oppression and presented as a 'holy war' to institute shari' $a$ and Islamic principles. Jihad in IS is erroneously defined religiously and justified on distorted political grounds. ${ }^{5}$ Jihad in radical Islamic thought is the only sure means of entering paradise. Muslims have no certainty of knowledge that their deceased loved ones are in paradise after death. Non-Muslim observers sometimes argue that no valid distinction exists between Islam and radical Islam. It is, however, the role of the Ulama [religious teachers] as the spiritual-intellectual authority that visibly separates the two. In a traditional Islamic state the measures the government takes or proposes is subject to the criticism by the Ulama, but in IS there is no such provision. The breeding ground of a radical version of religion and state can be attributed to 'the traditional ulama - the religious scholars who safeguard the tradition in the past has been displaced, not at least by young Islamists' (Huff 1995:516). In a politicalreligious movement such as IS, underpinned by radicalism:

religion then serves as a means of justifying a struggle that has been declared holy. Usually the holy books of religion are then interpreted in such a way as to sanction the 'holy war'. (Van der Walt 2007:164)

In IS, a hidden political agenda is masked by religious pietism whereas in the traditional Islamic states a dialogue takes place between religion and politics without there being an indiscriminate mixture of the two. In the same way dialogue needs to take place between state and religion in the public sphere in the West:

Muslim societies do have secular states, but the process of separation is much more contentious than societies, which do not have a codified religious law for society at the heart of their tradition. (Lim 2011:64)

4.'Whether religion contributes to violence, usually depends on the political, socia and economic circumstances especially where these contribute to (a group of) people feeling frustrated or threatened' (Van der Walt 2007:164).

5. "Jihad literally means "struggle". The greater jihad is the internal struggle to submit to God in the life of the Muslim believer. The lesser jihad is the struggle to advance Islam politically and militarily" (Pratts, Sills, \& Walters 2014:173).
This is, however, not the same for Shia's. A group called 'the Salafist jihadists', who are committed to what they see as the original meaning of the sacred texts of Islam, has also to be recognised as employing jihad. They combine the original meaning of the text with a total commitment to violent jihad and a belief that the United States is the greatest threat to their faith. The Salafi movement (often referred to as the Wahhabis) represents a diverse community, but all Salafis share a puritanical approach to the religion intended to eschew religious innovation by strictly replicating the model of the Prophet Muhammad. In the jihadist form of Salafi, the practice of takfir or excommunication is theologically perilous. 'If a man says to his brother, "O misbeliever! (You are an infidel)", the Prophet said, "Then surely, one of them is such"' (Khan 1996). ${ }^{6}$ If the accuser is wrong, he himself has committed apostasy by making a false accusation. The punishment for apostasy is death. Following takfiri doctrine,? IS has been committed to purifying the world by killing vast numbers of people.

\section{A historical overview of the coalesce of state and religion in Islam}

The historical coalesce of state and religion in Islam began with Abu Bakr, the successor of Muhammed in AD 632. 'The Prophet had not discussed political systems nor specified a political order to take over after his death' (Sonn 2004:23). It was Abu Bakr who, through a moral commitment to monotheism and political unity, referred to himself as the Prophet's representative (Khalifah or caliph) (cf. Sonn 2004:23). He united the state and religion through the Qur'an:

If they argue with you, say my followers and I have surrendered ourselves to God. And say to those who have received the Scripture and to the illiterate: 'Have you surrendered [to God]?' If they surrender [to God], then they are rightly guided, and if they turn away, then it is your duty only to preach. (Qur'an 3:20)

Diverse Arabic tribes and clans were unified under Abu Bakr through jihad just as IS through a radical recontextualisation of Quranic texts such as Qur'an 3:20 have attempted to unify the Arabic nations through the practice of jihad. It has been the practice of the Khalifah or caliph to use the Qur'an to distinguish between infidels and pure Muslims in order to unite Arabs under a pure Islam. In the same way IS has sought to restore a pure Islamic state. Shi'ite, as most Iraqi Arabs are, is to be regarded as not being Muslim, because IS regards Shi'ism as innovation, and to innovate on the Koran is so that it denies its initial perfection. It shows that a purist recontextualisation of Quranic texts is unable to deal with the later schism that took place between Sunni's and Shia's.

It was the highly influential jurist, al-Mawardi (AD 974-1058), who reasserted the unity of the religious and political order in Islam. 'He reaffirmed the authority of the caliph over all Muslim rulers' (Black 2010:119) and advocated for a

6.Sahih Al-Bukhari volume 8 Book 73 Number 125. Book of Good Manners and Form (Al-Adab).

7.In principle, the only group authorised to declare a member of an Abrahamic religion a kafir [unbeliever] is the ulema, and this is only done once all the prescribed legal precautions have been taken. 
restoration of a unified religious-political authority in Islam and a return of the caliph as at once the spiritual and political leader of the umma. The Abbasid era, stretching from AD 750 to 1258 , was the golden age of Islam. It was from the time of Ibn Taymiyya (1263-1328) that political culture and political thought in Islam became increasingly focused on religious sources (Black 2010:120). Ibn Taymiyya characterised his world as one of pagan ignorance, sin and lapse from the true faith (jahiliyya) and it was Maududi who gave a new currency to his thought for a characterisation of the contemporary world (cf. Huff 1995:507). The ideology of IS is a grabbing back at the past in the hope to restore the golden age of Islam. It is a return to a pure, unadulterated pattern of Islam reflected in the precedents set by the salaf (cf. Brown 2004:214). IS is intending to implement its view of law as 'religion and state' (din wa dawla) and does so in terms of the belief in the 'Rightly Guided Caliphs' (Salifs). Religion's authority in IS is subservient to political authority, although they give the impression of advocating for an unadulterated religious authority. The past is not readily accessible to reconstruct present political authority. The ideology of Islamic state was advanced by radicals in the 1930s and 1940s as the global cure for Muslim's to modernity (cf. Waines 1995:244). Mauluna Sayyid Abul-Ala Maududi ${ }^{8}$ was one the central protagonists against the influence of modernity and argued that 'the Muslim world should purge itself of the foreign elements and then wage jihad until all humanity was under Islamic rule' (Sardar 2003:30). He argues that 'Islam could not be limited by, or equated to, a nation-state' (Sardar 2003:29):

He accepted that the sharia contained many elements that are time-bound and not relevant to modern times. But his deep traditionalism prevent [ed] him from accepting that any changes can be made to sharia. (Sardar 2003:30)

Mohammed Akroun (1994) ${ }^{9}$ believes that his task was to help:

to dispel many Western misconceptions about Islam, and hopes to 'open a new historic phase', a phase in which 'critical thought anchored in modernity but criticising modernity itself' would aid and assist political decision making in the Muslim world. (p. 13; cf. Huff 1995:511)

Maududi in an answer to modernism conceived of shari'a law as a 'total system' and even though he accepted that 'the shari'a contains many elements that are time-bound and not relevant to modern times', and 'his deep traditionalism prevents him from accepting that any change can be made to shari'a' (Sardar 2003:30). It was the success of his ideological movement that produced a new society and state (cf. Sardar 2003), a version of an Islamic state with close parallels to IS which:

can now be seen in the North-west Frontier Province of Pakistan, where his followers are busy closing down cinemas, banning music, locking woman behind four walls, setting up religious

8. He founded the Jamaat-e-Islami [the Islamic Organization] party founded in Pakistan.

9.Mohammed Akroun is an emeritus professor on Islamic Thought after serving many years in Sorbonne, France. police to monitor vice, and generally establishing an ideal Islamic society. (p. 30)

The parallels are unmistakable with the distinction that IS has sought to set up an ideal Islamic society through extreme violence.

\section{The Islamic reaction to separation of the sacred and secular of 'Alī 'Abd al-Raziq (1888-1966)}

It is the relegation of religion to the private sphere and the consequent moral vacuum that has been interpreted as a counter cultural force to Arabic civilisation and has sparked the flame of radical Islam as a movement of cultural and religious preservation. There are many variations of Islamic states such as Turkey - based on secularist ideologies influenced by 'Abd al-Rāziq (1925), ${ }^{10}$ the more moderate secularism of Egypt ${ }^{11}$ and fundamental ideologies of Pakistan or Indonesia (cf. Brown 2004:214). Ali 'Abd al-Rāziq (18881966) and others emphasise that Islam is a way of life, while not denying the political character of Islam. In Malaysia parallel to the Shari 'a courts at the state level operates a system of secular courts, concerned with all other aspects of civil law' (Nagata 1994:67). Ali 'Abd al-Rāziq was dismissed as professor and Islamic judge for allegedly stating that Islam is a religious faith and not a system of government (cf. Tibi 1998:161). 'Abd al-Raziq is not simply an advocate for the separation of religion and politics, as he has been stigmatised, but endeavours to provide a scientific critique for alternatives to the view that state and religion in Islam are inseparable. Islam does not make a distinction between the public and private spheres and the consequence is that it tends towards totalitarian states (cf. Volf 2011:141). The views, advocated by Sayyid Qutb (1906-1966), ${ }^{12}$ are employed by radical Islamists in support of a radical Islamic state (IS). ${ }^{13}$ Qutab expresses the logical implications of Islam as a monotheistic religion, the belief in one God and in one universal law that there be only one single authority - a political and religious authority (cf. Volf 2011:141-142). The argument of radical Islam is that Western democracy and Christianity all over the world has been distorted by secularism. 'The Islamic marriage of religion with the state [which] is disapproved of in most corners of the globe' (Meneses 2006:238). In Islam, however, it is not the marriage of state and religion that is disapproved of, but the type of marriage which is an indiscriminate is IS blending. In Islam a dialogue takes place between state and religion in the public space and so for the ordinary, nonradical Muslim it is the subservience of the state's authority to a radicalised religious authority that is to be rejected. Islam is based on Shari'a law as a universal set of moral values to

10.It is "Abd al-Răziq who drew a sharp distinction between prophetic authority and political authority.

11."Al-'Awwa is a respected lawyer in Cairo and one of the most significant leaders of the movement of al-Ikhwan al-Muslimun/the Muslim Brethren" (Tibi 1998:164). Mohammed Salim is the former secretary-general of the International Union of Muslim Scholars and the head of the Egyptian Association for Culture and is one of the 500 most influential Muslims.

12.Sayyid Qutb asserted that, in the absence of a legitimate Islamic state, jihad becomes the duty of Muslims as individuals (cf. Brown 2004:229).

13.'Qutb's is not the Islamic position; indeed, his views have been explicitly condemned by many Muslims and do not represent the mainstream of Islam (Volf 2011:142). 
regulate public morality and so it is more than a religion. Mohammed Salim Al'Awwa (1942-), ${ }^{14}$ who has aligned Islam to the Western values, has been criticised for mistakenly assuming that Western values of democracy are universal, and for this reason, is seen as a liberal voice within Islam. The constitution of Malaysia defends individual rights and freedoms, including those of ethnic and religious minorities and women (cf. Nagata 1994:85):

Much of the government's success in sustaining its own development programs (and power) lies in the management of the legal system, with its complex heritage of conflicts and overlaps between religious and secular courts. However, many legal uncertainties and lacunae persist, even to the definition of the boundaries of the ummah, in the marginal cases of converts, mixed marriages and apostates, which test the limits of a multireligious society. (Nagata 1994:85)

It is vulnerable to destabilisation either in the local political scene or in the Muslim community at large (cf. Nagata 1994:86).

\section{Unity of state and religion advocated by Assad Khalil al-Najjar (1881-1974)}

Al-Najjar argues that Islam is disposed towards dialogue between state and religion in the public sphere. For him the contention of din wa dawla [unity of religion and state] in Islam is nothing but a recent tradition. The state is restricted to a limited and specific group of people, that is the citizens (cf. Tibi 1998:165). Al-Najjar has postulated that the relation between state and religion are vested in the umma, in the understanding of 'the people', as the source of all powers. Tibi (1998:167), however, contends 'that this idea has guided political thought in Islamic history cannot be supported by any study of Islamic history of ideas, for it is, rather, a recent addition'. For Al-Najjar, Islam is unquestionably a political religion, although not providing a concept for IS, but in outlining a political ethic for governing a polity. Al-Najjar deploys the classical notion of umma against the newly introduced notion of din wa dawla, the unity of state and religion, and repeatedly argues that it is not the business of Islam to furnish a system of government (cf. Tibi 1998:166). Umma or religious scholars provided fatwas or opinions on matters, but law was left to the rulers. Sometimes the rulers abided by the religious scholars. In other cases they used their own secular (urf or mutzalim) rulings. IS, however, does not make use of umma. The absolute separation of politics and religion leads to secularism as is the case in the West. However, the identification of political rule as religious leads to fundamentalism as is the case with IS. These are two totalitarian extremes. 'It reduces the entire worldview and way of life that Muslims are so proud of to a narrow religious affair restricted to the mosque and to the personal' (Van der Walt 2007:163). 'Many in Western societies are now absolutely convinced that there should in fact be no relationship whatsoever between Christian morality and public law'

14.Readers of the passage who forget the political context will take the statement of Jesus in Mark 12:17 at face value and may be inclined to think that either no separation or an absolute separation of spheres, political and religious, is inclined.
(Mohler 2008:8). In Islamic civilisation the prolific debate is the nature of the relation between state and religion whereas in Western civilisation the main debate is about the separation of state and religion.

\section{The separation of religion and state advocated by Mohammed Salim al-'Awwa (1942-)}

'Al-'Awwa claims that Islam provided the first authentic political and legal system of state in the history of mankind' (Tibi 1998:159). The reason is that Shari'a or Islamic law has a legal underpinning in the state. Islam is a political system as much as it is a religious one (cf. 'Abdulmawala 1973). He argues that Islam is a din wa dawala. Islamic scholars, however, are divided over this matter. Al-'Awwa's primary contention is the relation and the goal of the traditional Islamic state and the establishment of the Islamic religion. 'He names five constitutional provisions of Islamic rule: shura/constitution, al'adl/justice, al-hurriya/freedom, al-musawah/equality, and musa'alat ra'is al-dawla / accountability of the head of the state' (Tibi 1998:164). The critique of al-'Awwa is that he is vague and projects modern concerns into Islamic history (cf. Tibi 1998:164). The constitutional provisions of al-'Awwa is part of his attempt to relate Islam to a Western constitutional approach in which religion and state are completely separate. 'Continuing to impose the Western view of democracy and human rights in Islamic or any other non-Western civilisation affords little promise' (Tibi 1998:180).

\section{The relation of religion and state in the Islamic state, and individualism and collectivism}

Anthony Black (2010:116) argues that differences between Christianity and Islam 'may in part be explained by the fact that the complexities of early Christianity and early Islam were almost diametrically opposed'. A modern Western state has tended towards an individualistic value system and individualistic self-governance as well as the sociophilosophy of individualism whereas the Islamic state has tended towards a group value system and the sociophilosophy of collectivism. Fatima Mernissi affirms that in the Arab-Muslim world is a great fear of democracy, of freedom, of thought and expression, and of individualism (cf. Huff 1995:515). 'Mernissi seeks to reactivate the rationalist tradition of the Mu'tazilites, the 9th century philosophers who borrowed from the Greeks and championed rationalist approaches to human and theological dilemmas' (Huff 1995:513) for freedom of thought and expression. The 'Mu'tazilitī conception of God's justice is retributive' (Hoover 2006:58) and influenced the Shia schools whereas the Ash'arī view of God's justice is voluntaristic (cf. Hoover 2006:58) and is representative of all four Sunnī schools of thought. Ibn Taymiyya's own position is a third way - 'defines justice as putting things in their proper places' (Hoover 2006:57):

Ibn Taymiyya attacks Mu'tazilites both for obligating God to act according to a retributive ethic and for misconstruing the divine economy in such a way that makes God look foolish and undermines thankfulness to Him. (Hoover 2006:58) 
Samuel Huntington (1993) published a controversial article called the 'Clash of civilizations' in JSTOR, in which he argues that the differences between the West and the ArabIslam world can be attributed to a struggle of worldviews of people belonging to different cultures and civilizations. ${ }^{15}$ He most unfortunately overlookeds the crucial distinction between Islam as a religion, and IS which is based on a radical and fundamentalist ideology (cf. Tibi 1998:181). The culture of collectivism is the antithesis of democracy (cf. Tibi 1998:182). It is because of the collective nature of Islamic culture that fundamentalism has proven to be more authentic in Islamic civilisation than democracy. 'Samuel Huntigton prematurely, for one announced a "Third Wave", in the course of which global democratization would come about' (Tibi 1998:182). In IS what we are seeing as a result of the crises is not a new wave of democratisation, but a new kind of authoritarianism. 'Fundamentalism, borne out of the crises of nation-state, is this new brand of authoritarianism, and indeed we are witnessing its rise on a global scale' (Tibi 1998:181).

In order to compare the relation between religion and state in the Islamic world to the West, the diverse historical development in the West has to be taken into consideration.

\section{The separation of the church and state in the West}

The relation between church and state in the West has been confined to the broad identification of the historical influences on the relation.

\section{Charlemagne's influence on the relation and church and state (AD 747-814)}

The emperor, Charlemagne (AD 747-814), began to exercise authority over the church. The coronation of Emperor Charlemagne in a symbolism in which Pope Leo III placed the crown on his head, marked a turning point and the beginnings of a historical period in which the church became involved in politics. Politics and religion were mixed - 'an elaborate mixing of elements' (Noll 2012:108). 'It represented a strategic alliance between the papacy's gradually expanding influence and a political power that, like the pope, was also expanding in influence' (Noll 1998:109) and was the beginning of the struggle between church and state, politics and religion, and faith and reason. ${ }^{16}$

\section{The origins of problem of the relation between state and religion in the West (AD 750-1200)}

One of the reasons that there was a political struggle between the Pope and Caesar was because of an underlying dualistic worldview. It was the beginning of the secularisation of politics

15.The Clash of Civilizations (COC) is a hypothesis that people's cultural and religious identities will be the primary source of conflict in the post-Cold War world. It was identities will be the primary source of conflict in the post-Cold War world. It was proposed by political scientist, Samuel P. Huntington, in a 1992 lecture at the American Enterprise Institute which was then developed in a 1993 Foreign Affairs

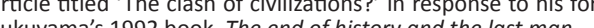
Fukuyama's 1992 book, The end of history and the last man.

16.It is an erroneous inference that it was the relationship of state and church that secured the future dominance of Christianity.

\begin{tabular}{|ccccccc|}
\hline Pope & God & Scripture & Faith & Church & Grace & Soul \\
\hline Emperor & World & Sciences & Reason & State & Nature & Body \\
\hline
\end{tabular}

Source: Original representation of the dualism of early Christianity.

FIGURE 1: The dualistic worldview perpetuated in the relation of the false dichotomy between religious and secular.

and religion and the hostile separation of state and church. A political and moral chaos from around AD 850 to 1000 plagued the church. The church and state were indiscriminately blended and so began the conflict of politics and religion. The indiscriminate blending influenced the religious convictions of the Christendom and the sacraments became a political instrument in the struggle between the usurpation of the church's authority over the state (see Figure 1).

\section{The consequence of a blending of politics and religion: The schism between West and East (AD 1054)}

The schism between the West and Eastern Church of 1054, ${ }^{17}$ although doctrinally substantiated, ${ }^{18}$ was essentially a schism over the indiscriminate blending of church and state, politics and religion. The second consequence of the indiscriminate blending of church and politics was that the politics was sugar coated with the religious - political motivations usurped the religious. The relation between church and state was not successful, because the autonomy of spheres of society and their roles and relation had not yet been developed until the time of Abraham Kuyper (1837-1920).

\section{Reformation: A response to the indiscriminate blending the roles of church and state (AD 1600)}

The Reformation had the effect that Catholic church-state establishments in much of Germany, Switzerland, the Netherlands, England, Wales and Scandinavian countries were replaced by Protestant church-state establishments. The blending of state and church relation continued, but the church was reformed so that there was no longer an indiscriminate blending of the spheres of authority of the state and church. 'Although church and state were distinct, the church had an active role to call the state to account' (Lim 2011:64). The Reformation restored the independence of the political, social, economic and cultural spheres and related all of life to the church. The rediscovery of the Reformation was that all of life was directed towards God. ${ }^{19}$ In the reformed view human existence is essentially directed in a relation of accountability towards God.

The response of the later development of the Reformation to the continuing blending of church and state was to introduce the

17.'No event had greater impact on Eastern Christianity before the Muslim capture of Constantinople in 1453' (Noll 1998:130) than the schism of AD 1054.

18."No event had greater impact on Eastern Christianity before the Muslim capture of Constantinople in 1453" (Noll 1998:130) than the schism of 1054

19.Luther's church-state view was to regard the political order as an independent dimension (cf. Sanders 1964:48). The church-state relation 'lost its relation to God's sovereignty, justification, love and vocation' (Sanders 1964:48). 


\begin{tabular}{cccc|}
\hline Soul & Church & Eternal & Spirit \\
\hline Body & State & Temporal & Flesh \\
\hline
\end{tabular}

Source: Original representation of the dualistic structure in modern Christianity.

FIGURE 2: The dualistic relations and false dichotomies that continued after the reformation.

fundamental idea of subsequent reformation thinking. This implies that the church and state had to evaluate its relation to God in terms of the two directional choices: obedience and disobedience in all spheres of authority. The reformed principle is the sufficiency of Scripture and it is Scripture that provides the framework for this directional choice.

For Calvin both magistrates and ministers were committed to the same task, the difference between them lying in the tools they had available and their respective spheres of authority. Both magistrates and ministers were agents and servants of the same true God, committed to the same cause, differing only in their spheres and means of action. (McGrath 1999:233)

Yet, in Geneva there was trouble more than once through tensions between the two authorities, spiritual and temporal, because the Reformation had not as yet completely departed from the previous paradigm through its continuance to maintain certain dualistic relations. Calvin was a member of the Consistory and so he was able to make representations to the magistracy on behalf of the ministers. For Calvin the ministry had the right to explain to the magistracy what the Word of God required in a given situation. The essential issue is that the government can resist the advice of the ministry, because the relation between the state and church is not based on theocracy (see Figure 2).

\section{The modern Western state: A state without moral boundaries}

We live in the era of 'nation-states' writes Meneses (2006:233). 'In nation-states, especially in those that are democrat[tic], there is understood to be no excuse for a lack of allegiance to the government' (Meneses 2006:234). The modern conception of the nation-state, governed by values, is foreign to Arabconceptual thinking. The modern-state is characterised by self-rule (vs. foreign rule), religious freedom, democracy, egalitarian justice, territorially based citizenship and ethnic pluralism (cf. Meneses 2006:238). These democratic values are 'secular values' to which individuals and the head of the state are held accountable in a Western state. Western states have demanded loyalty to these identified 'democratic norms', and in so doing, have marginalised 'religious norms'. The West has made a distinction between the secular and the sacred in order and to separate public from private norms and marginalised religious norms to the private sphere. Western democracy comes at a high price - that of undermining religious norms and direction. ${ }^{20}$ Secular norms are individualistic in nature while there are commonality between the norms of Islam and Christianity in that they are collective in nature and covenantal in reformed Christianity. One of the ways of addressing this problem is through the identification of a set of universal norms - norms which are contributed to by both the state's 'democratic norms' and religion's 'moral norms'. Before there can be a common morality and 'common norms', both Islam and Christianity has to be clear as to what are the universal norms and to actively oppose the imposition of fundamentalist norms of a minority upon the majority.

\section{The distinct historical point of departure between Christianity and Islam in the relation of state and religion}

It is the respective diverse historical starting points of Christianity and Islam with regard to the relation between state and religion that led to completely different understandings of the relationship between politics and religion.

The first Christians saw the state as quite separate from their concerns Islam, by contrast, set off with an all embracing political and social agenda: God's message entailed world rule by Muhammed and his successors (or caliphs: deputies). (Black 2010:116, 117)

There are elements conducive to democracy in Islamic society, but in essence, Islamic reform has different points of departure from Christian reform. Bernard Lewis (2007:69) comments on the relation between culture and society as follows: 'different societies develop different ways of conducting their affairs, and they do not need to resemble ours'. Applied to the relation between state and religion, and the development of a democratic state, he (Lewis 2007:69) writes: 'Democracy comes in stages, and the stages and process of development will differ from country to country, from society to society.' Lewis (2007:70) is cautiously optimistic when he expresses that the cause of developing free institutions - along their lines, not ours - is possible. At the same time the forces working against it are very powerful and well entrenched.' He (Lewis 2007:70) concludes: 'Either we bring them freedom, or they destroy us.' The Reformation gave to us religious freedom and perhaps a social philosophy, birthed out of a reformed tradition, could bring new perspectives to a stalemate in the relation between state and religion in the West and Arab-Muslim world.

\section{The points of departure of the modern reformed view of church, state and society}

The modern reformed view developed long after Calvin and pursues the ideal of a diversity of equal relationships standing next to one another (cf. Van der Walt 2010:442). Societal relationships are not a mere human invention or social contract, but a capacity built into creation by God and subject to God's norms (cf. Van der Walt 2010:442). 'Every societal relationship has within its own sphere particular competence and its own kind of authority and power' (Van der Walt 2010:442). In this approach there is no higher against lower scheme, according to which one relationship (e.g. the state or church) has a higher status than the other. Authority and power is abused when the norms, governing each of these social structures, are disregarded. In Islam social 


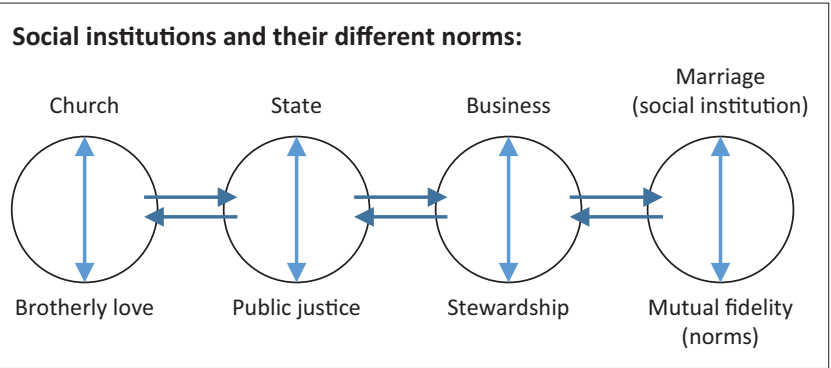

Source: Original representation by B.J. Van der Walt of Abraham Kuyper's spheres of society. FIGURE 3: Diagrammatic representation of the directional choice between obedience and disobedience in Christian religious norms that govern Western social institutions.

institutions are also identifiable governed by certain universal norms. In radical Islam, represented by IS, the norms, which govern social institution, are indiscriminately blended with political norms, that is, political loyalty to the caliph in IS takes precedence over all religious norms (see Figure 3).

\section{The separation of church and state, and the public and private sphere}

It is the theologian, Abraham Kuyper (1837-1920), who made the most significant contribution to the development of separate spheres of society. It is also Kuyper who advocated for the active role of Christians to call the state to account, which is correct. It is, however, his view that all of society, including the state, had to be brought under the reign of the present Lordship of Christ, which has been misinterpreted, as the church exercising a moral authority over the state and has led to the blending of church and politics in the Apartheid regime. In South Africa a problem occurred when the norms, prescribed for all the citizens of the country, were not universal norms, but the norms of one religious segment, namely the Protestant church (and even this was limited to reformed churches).

Western Christians have confined 'Christian moral norms' to either ecclesiastical institutions like the church or the private sphere and made morality a private matter. This it has resulted in lesser justice, freedom and prosperity for all. The alternative, however, of prescribing 'Christian moral norms' for all of society is an equally harmful deviation:

The church has always acknowledged the tension between loyalty to the state and loyalty to God, ever reserving the right to listen to God rather than to human authorities (Acts 4:19). (Ott \& Netland 2006:232)

When the church listens at two different voices, the state and conscience, given by God to the community, it has to be prophetically discerning. The only way forward is for the church to be a prophetic voice that is not defined by social structures, but is able to speak to caution against social evils. The role of the state is to create an environment for the proclamation of the gospel ( $\mathrm{Rm} \mathrm{13:1-7)}$ and not to enforce 'Christian moral norms'. It is not the reformist model which itself was defective, but the 'attempt to remake the world into their own image and often fail to think through how they might live together with those with whom they disagree' (Wolterstoff 1993:22).

\section{The third way of structural pluralism and confessional pluralism}

Structural and confessional pluralism is an alternative for religious expression in both an Islamic and Western society.

\section{Structural pluralism}

The solution to either the indiscriminate blending of spheres or the absolute separation thereof is structural pluralism. It advocates for social structures that are neither solely independent (they exists side by side) nor unrelated, but are interrelated. All the structures are equal in authority, power and responsibility. It is based on the recognition that no single social structure can bear all the authority and be totally responsible, that is, state or church.

\section{The state and structural pluralism}

In the structural plural model the role of the state is to protect and ensure that each societal structure has only limited authority. 'Every bearer of authority has only a restricted and specific responsibility' (Van der Walt 2010:479). The state in this model also only has limited authority and responsibility. The role of the state is to ensure that each societal structure is limited in its authority, power and responsibility. In structural pluralism the groups do not exist for the sake of the state, that is, the state is not the ultimate authority in matters. Structural pluralism is a totally different social perspective than individualism and collectivism.

\section{Confessional pluralism}

In the relation between religion and state an alternative is necessary in which the secular and sacred dualism is replaced by choice in direction of obedience or disobedience to God, called confessional pluralism. Confessional pluralism allows for a multiplicity of religious views, each contributing to the welfare of the state. Thus, both Islam and Christianity can contribute to the welfare of the state. The role of the constitution then of the state is to protect and uphold the multiplicity of religious views, the sovereignty of the different spheres or social institutions of society. Confessional pluralism is not a compromise between individualism and collectivism. It offers a third alternative, not merely a synthesis of two views. Confessional pluralism asserts that every society relationship should have the right to publicly make known and live out its own religious convictions. 'Jewish, Muslim, Christian and parents should, for instance have the right to found schools according to their own religious convictions' (Van der Walt 2010:480). The role of Western courts is to ensure that not one religious community's laws would be accepted, because they are deontologically revealed as religious law. The importance of confessional pluralism is that it 'prevents both religious anarchy and totalitarianism' (Van der Walt 2010:480). Confessional pluralism has the benefits of structural pluralism that all societal institutions are invested with equal authority, but it allows for 'Christians moral norms' and 'Muslim moral norms' in the public sphere. 


\section{The impartiality of the state and the duty to uphold} confession pluralism

In confessional pluralism the impartiality of the state does not contradict or prohibit the separate functioning of the state as a separate sphere of society from religious institutions which function as a sphere in the same social space. Firstly, the state cannot be responsible for all justice, but only for public justice otherwise it will result in the creation of a totalitarian state; secondly, the absolute authority of the state is limited by the voluntary accountability of the state to the institutions of society. The state is to be accountable to all institutions and not favour one particular institution. The task of every social institution is to contribute the creation of a set of collective norms; thirdly, Wolterstoff (1993:45) interprets the neutrality requirement of the state, namely that the state be neutral with respect to religious and other comprehensive perspectives present in society as requiring impartiality rather than separation; and fourthly, the impartiality of state and religion is important in plural societies, because 'it frees the state from control by the church' and 'it manages religious diversity within pluralistic societies' (Vorster 2007:117-118).

\section{The need for common political and religious norms}

Political realities are not external to social spheres of authority and moral responsibility (cf. Meneses 2006:249). All political structures, ideologies and motivations are to be subordinated to universal norms. 'Religious law is at the heart of Islam, and to ignore it is to cut at the heart of the religious authority of the Koran, the traditions, and the example of Muhammed' (Lim 2011:64). It is not a separation in terms of spheres into public and private, but a recognition of the autonomy of different spheres of authority and that this spheres are to serve the common good that is the basis of peaceful human co-existence. Confessional pluralism allows for a multiplicity of religious views, each contributing to the welfare of the state. The constitution of the state protects and upholds the multiplicity of religious views and provides a common system of norms to unite all norms as well as religious norms for the common good. Islam does not make a distinction between the public and private spheres. It makes a dualistic separation which is correct, but IS has blended politics and religion - two separate spheres of society, and so much like under the South African Apartheid government, has succumb to the same enforcement of religious norms of one segment of the population for all. In a multi-global world the Western democratic system of 'secular norms' has been taken as universal moral norms and it is this that is the breeding ground for a clash between Western and Islamic civilisation.

\section{Conclusion}

The relation between state and religion in the Western society has developed historically. It has developed from the dominance of the state to a coexistence of state and church and then to the hostile separation of state and church. Confessional pluralism advocates for an interrelations blending, but not an indiscriminant blending. The alternative is a complete separation of state and church in the modern democratic state that will continue to place cohort pressure on the Islamic world to adopt the same separation. The relation between state and church in Western society has been shaped by the philosophy of dualism - a dualism that tends to complete separation. The historical development of Islam has been marked with a similar, although not identical tension between state and religion. The recent assurgency of IS is a symptom of the tension. IS may disappear, but the tension will continue to remain and threaten to raise its head unexpectantly. The social philosophy of confessional pluralism provides an alternative that can defuse the tension leading to greater polarisation between Western and Arab-Muslim society and between these two beautiful civilisations.

\section{Acknowledgements Competing interests}

The author declares that he has no financial or personal relationships which may have inappropriately influenced him in writing this article.

\section{References}

'Abdulmawala, M., 1973, The organization of society and state in Islam (Anzimat al-mujtama' wa al'dawla fi al-Islam), al-Sharika al-Tunisiyya, Tunis.

Akroun, M., 1994, Rethinking Islam, transl. R.D. Lee, Westview Press, Boulder, CO.

Black, A., 2010, 'Religious politics in western and Islamic thought: A clash of epistemologies?', Political Quarterly 81(1), 116-122. https://doi.org/10.1111/ j.1467-923X.2009.02065.x

Boer, J.H., 2009, 'Christians and Muslims: Parameters for living together', in J.H. Boer, Studies in Christian-Muslim relations, vol. 2-8 pp. 128-163, Essence Publishing, Belleville, Ontario, Canada.

Brown, D., 2004, A new introduction to Islam, Blackwell Publishing, Malden, MA.

Fukuyama, F., 1992, The end of history and the last man, Avon Books, Inc, New York.

Hoover, J., 2006, 'The justice of God and the best of all possible worlds: The theodicy of Ibn Taymiyya', Theological Review 27(2), 55-75.

Huff, T.R., 1995, 'Rethinking Islam and Fundamentalism', Sociological Forum 10(3), 501-518. https://doi.org/10.1007/BF02095834

Huntington, S.P., 1993, 'The clash of civilizations?', Foreign Affairs 72(3), 22-49. https://doi.org/10.2307/20045621

Khan, M.M., 1996. Sahih al-Bukhari fi Nadhm Jadid. Darussalam.

Lewis, B., 2007, 'Freedom and justice in Islam', Society 44(2), 66-70. https://doi. org/10.1007/BF02819929

Lilback, P.A., 2012, Wall of misconception: Does the separation of church and state mean the separation of God and government?, 2nd edn., Providence Forum Press, Westminster Theological Seminary, Glenside, PA.

Lim, D.S., 2011, 'Mission as transformation: Holistic, ecumenical and contextual', in S.J. Roels \& S. Nomi (eds.), Reformed mission in an age of world Christianity: Ideas for the 21st century, pp. 57-72, The Calvin Press, Grand Rapids, MI.

McGrath, A.E., 1999, Reformation thought: An introduction, 3rd edn., Blackwell Publishers, Oxford, UK.

Meneses, E.H., 2006, 'Bearing witness in Rome with theology from the whole church: Globalization, theology, and nationalism', in C. Ott \& H.A. Netland (eds.), Globalizing theology: Belief and practice in an era of world Christianity, pp. 231-249, Baker theology: Belief and practice
Academic, Grand Rapids, MI.

Mohler, R.A., 2008, Culture shift: Engaging current issues with timeless truth, Colorado Springs, Multnomah, $\mathrm{CO}$

Nagata, J., 1994, 'How to be Islamic without being an Islamic state: Contested models of development in Malaysia', in A.S. Ahmed \& H. Donnan (eds.), Islam, globalization and postmodernity, pp. 63-90, Routledge, London.

Noll, M.A., 1998, Turning points: Decisive moments in the history of Christianity, Baker, Grand Rapids, MI.

Noll, M.A., 2012, The new shape of world Christianity: How American experience reflects global faith, IVP Academic, Downers Grove, IL.

Ott, C. \& Netland, H.A., 2006, The values of Islam and Christianity are corporate as opposed to individual in nature, Baker Academic, Grand Rapids, MI. 
Sanders, T.G., 1964, Protestant concepts of church and state, Holy, Rinehart \& Winston, New York.

Sardar, Z., 2003, 'Maulana Sayyid Abul-Ala Maududi', New Statesman 132(46) 28-30.

Shokri, M., 2016, 'Islam and politics: The case of Islamic State', Studia Humana 5(2), 3-12. https://doi.org/10.1515/sh-2016-0006

Sonn, T., 2004, A brief history of Islam, Blackwell Publishing, Oxford, UK.

Tibi, B., 1998, The challenge of fundamentalism: Political Islam and the new world disorder, 2nd edn., University of California Press, Berkeley, CA.

Turaki, Y., 2010, Tainted legacy: Islam, colonialism and slavery in northern Nigeria, Isaac Publishing, Mclean, VA.

Van der Walt, B.J., 2007, Transforming power: Challenging contemporary secular society, Institute for Contemporary Christianity in Africa, Potchefstroom.
Van der Walt, B.J., 2010, At home in God's world: A transforming paradigm for being human and for social involvement, Institute for contemporary Christianity in Africa, Potchefstroom.

Volf, M., 2011, A public faith: How followers of Christ should serve the common good, Brazos Press, Grand Rapids, MI.

Vorster, N., 2007, Restoring human dignity in South Africa: Christian anthropology in a new dispensation, Potchefstroom Theological Publications, Potchefstroom.

Waines, D., 1995, An introduction to Islam, 2nd edn., Cambridge University Press, Cambridge, NY.

Walls, A.F., 1996, The missionary movement in Christian history: Studies in the transmission of faith, Orbis, Maryknoll, NY.

Wolterstoff, N., 1993, What New Haven and Grand Rapids have to say to each other, Calvin College Seminary, Grand Rapids, MI. 